\title{
Cost analysis of a coal-fired power plant using the NPV method
}

\author{
Ravinder Kumar $^{1} \cdot$ Avdhesh Kr. Sharma $^{2}$ • P. C. Tewari ${ }^{3}$
}

Received: 5 November 2014/Accepted: 30 May 2015/Published online: 23 June 2015

(c) The Author(s) 2015. This article is published with open access at Springerlink.com

\begin{abstract}
The present study investigates the impact of various factors affecting coal-fired power plant economics of $210 \mathrm{MW}$ subcritical unit situated in north India for electricity generation. In this paper, the cost data of various units of thermal power plant in terms of power output capacity have been fitted using power law with the help of the data collected from a literature search. To have a realistic estimate of primary components or equipment, it is necessary to include the latest cost of these components. The cost analysis of the plant was carried out on the basis of total capital investment, operating cost and revenue. The total capital investment includes the total direct plant cost and total indirect plant cost. Total direct plant cost involves the cost of equipment (i.e. boiler, steam turbine, condenser, generator and auxiliary equipment including condensate extraction pump, feed water pump, etc.) and other costs associated with piping, electrical, civil works, direct installation cost, auxiliary services, instrumentation and controls, and site preparation. The total indirect plant cost
\end{abstract}

Ravinder Kumar

rav.chauhan@yahoo.co.in

Avdhesh Kr. Sharma

avdhesh_sharma35@yahoo.co.in

P. C. Tewari

pctewari1@rediffmail.com

1 Department of Mechanical Engineering, Maharishi Markandeshwar University, Mullana, Ambala, Haryana, India

2 Department of Mechanical Engineering, Deenbandhu Chhotu Ram University of Science and Technology, Murthal, Sonepat, India

3 Department of Mechanical Engineering, National Institute of Technology, Kurukshetra, India includes the cost of engineering and set-up. The net present value method was adopted for the present study. The work presented in this paper is an endeavour to study the influence of some of the important parameters on the lifetime costs of a coal-fired power plant. For this purpose, parametric study with and without escalation rates for a period of 35 years plant life was evaluated. The results predicted that plant life, interest rate and the escalation rate were observed to be very sensitive on plant economics in comparison to other factors under study.

Keywords Net present value - Economic analysis . Escalation rate $\cdot$ Thermal power plant

\section{List of symbols}

$\begin{array}{ll}a_{i}, b_{i} & \text { Values of constant obtained through curve fit } \\ \mathrm{Av}_{\text {overall }} & \text { Overall plant availability } \\ C_{i} & \text { Component cost } \\ C_{o} & \text { Total operating cost } \\ C_{s} & \text { Labour average annual salary } \\ C_{\mathrm{cc}} & \text { Fuel cost per tonne } \\ C_{\text {direct }} & \text { Direct plant cost (INR) } \\ C_{\text {indirect }} & \text { Indirect plant cost (INR) } \\ C_{\text {Eqp }} & \text { Cost of equipment (INR) } \\ C_{\text {piping }} & \text { Cost of piping (INR) } \\ C_{\text {pumping }} & \text { Cost of pumping (INR) } \\ C_{\text {coalhandling }} & \text { Cost of coal handling (INR) } \\ C_{\text {ashhandling }} & \text { Cost of ash handling (INR) } \\ C_{\text {other }} & \text { Other costs due to direct installation, } \\ & \text { auxiliary services, instrumentation and } \\ C_{\text {tci }} & \text { controls and site preparation (INR) } \\ C_{\text {coal }} & \text { Total capital investment (INR) } \\ C_{\text {ins }} & \text { Coal cost (INR) } \\ C_{\text {lab }} & \text { Insurance cost (INR) }\end{array}$




\begin{tabular}{|c|c|}
\hline$C_{\text {maint }}$ & Maintenance cost (INR) \\
\hline$f_{\mathrm{MW}}$ & $\begin{array}{l}\text { Percentage of net electric energy power plant } \\
\text { output assumed as } 90 \% \text { of MW available for } \\
\text { sale }\end{array}$ \\
\hline$f_{\text {conversion }}$ & A conversion factor \\
\hline$i$ & Interest rate \\
\hline$J$ & Escalation rate of labour salary \\
\hline$K$ & Escalation rate of fuel cost \\
\hline$K$ & kth year \\
\hline MW & Plant capacity \\
\hline$m_{j}$ & Mass flow rate through the ${ }^{\mathrm{j}} \mathrm{j}$, pump \\
\hline$m_{\mathrm{coal}, k}$ & $\begin{array}{l}\text { Coal consumption rate at the 'kth' year } \\
\text { (tonne/h) }\end{array}$ \\
\hline$n_{L}$ & Number of labourers employed \\
\hline $\mathrm{NPV}_{\text {lifetime }}$ & Plant lifetime net present value \\
\hline$O$ & Escalation rate of insurance cost \\
\hline $\mathrm{Pl}$ & Plant life (in years) \\
\hline $\mathrm{PWF}_{k}$ & Present worth factor at the 'kth' year \\
\hline$Q$ & Escalation rate of maintenance cost \\
\hline$R_{\text {an }}$ & Revenue earned (INR) \\
\hline$R_{\text {lifetime }}$ & Plant lifetime revenue earned (INR) \\
\hline \multicolumn{2}{|c|}{ Greek symbols } \\
\hline $\begin{array}{l}\text { Fac } \\
\text { inst }\end{array}$ & $\begin{array}{l}\text { Factor for direct installation, auxiliary, } \\
\text { instrumentation and control }\end{array}$ \\
\hline$\eta_{\text {pump }} \quad$ Pun & Pump efficiency \\
\hline $\begin{array}{l}\text { Fac } \\
\text { up }\end{array}$ & $\begin{array}{l}\text { Factor to account for engineering and plant start- } \\
\text { up }\end{array}$ \\
\hline
\end{tabular}

\section{Introduction}

Profitable capital investment leads to the growth and prosperity of an economy. If profitability is low, investment will shrink. These economic indices provide a basis to evaluate the net present value index for the analysis of process industries. However, there is considerable scope for a coal-fired electric power generation facility to be costeffective. The objective of the present work is to achieve profitable capital investment in a $210 \mathrm{MW}$ coal-fired thermal power plant situated in north India. Thus, a balanced integration of the cost analysis module of coal-fired power plant and economics needs to be carried out, so that the power plant economic indices of coal-fired power plant in terms of total capital investment, operating cost (i.e. fuel cost, operations and maintenance cost), revenue and net present value could be analysed. The basis of most design decisions is economic; thus, economical consideration plays a significant role as the economics of coal-fired power plant is closely associated with technical aspects. Various methods have been developed for controlling the economics of thermal power plant, namely annual cost method, capitalized cost method and present worth method.
Peters et al. (1991) proposed that to account for the cost of the investment, the total capital cost must be placed on an annual basis (i.e. due to interest accumulated on the investment, depreciation, maintenance, insurance and taxes). There is always deterioration of equipment life and thus its depreciation cost loses value.

Researchers reported considerable work on economic analysis using the net present worth method in various process industries. Remer and Nieto (1995) presented 25 techniques implemented to make an assessment of the economic desirability of projects. They categorized them into five types, viz., net present value methods, rate of return methods, ratio methods, payback methods and accounting methods. They provided insight into the advantages and limitations of these project evaluation methods by comparing and contrasting them. Manninen and Zhu (1998) presented a new methodology which combines the benefits of thermodynamics, economics and mathematical optimization for the new design of power plants. Giri and Dohi (2004) implemented the net present value approach to determine the economic manufacturing quantities for an unreliable production system over an infinite planning horizon. From numerical experiments, it was observed that the decision based on the average cost can be $10 \%$ worse than the decision based on net present value depending upon the machine failure rate. Caputo et al. (2005) investigated and evaluated the feasibility of using biomass to provide electricity in combustion and gasification plants. Moreover, to evaluate the impact of logistics on the bio-energy plant's profitability, the effects of main logistic variables such as specific vehicle transport costs, vehicle capacity, specific purchased biomass costs and distribution density have been examined. Davison (2007) presented performance, cost and emissions data for coal and natural gas-fired power plants, based on information from studies carried out recently for the IEA Greenhouse Gas research and development programme by major engineering contractors and process licensors. Madlener and Stoverink (2012) discussed the economic feasibility of constructing a $560 \mathrm{MW}$ coal-fired power plant in Turkey, using real options theory. They developed a sequential investment model based on the binomial tree model. They found that the real option analysis can be very useful, especially in the strategic planning of projects. Zhang et al. (2013) presented a detailed method for the estimation of straw-based power generation and concluded that the cost of straw-based power generation is indeed higher than the coal-fired power generation with life cycle analysis. Numerous studies were conducted on cost/economic analysis; the empirical relations to represent the cost of components/equipment in thermal power plant are relatively scarce and age old. From literature survey, it was observed that less work was found to be related to the cost 
analysis of the thermal power plant and it was difficult to arrange the various component costs of the plant by any empirical relation. The present study deals with the cost analysis of the thermal power plant and the parametric study results have also been represented in the plant lifetime cost. To achieve this goal, the data for each equipment/component cost in terms of power output capacity have been obtained from the literature search, which is not common in open literature.

\section{Economic analysis module}

To have a realistic estimate of primary components or equipment, it is necessary to include the latest cost of these components. Thus, the data for costs for each equipment/component of the plant in terms of power output capacity was obtained from literature search (Caputo et al. 2005; Hasler et al. 2009; Pauschert 2009; NETL 2012), and the cost of each component is fitted using power law in terms of installed capacity of the plant. The cost of the $i$ th component $\left(C_{i}\right)$ is defined as

$C_{i}=a_{i} \mathrm{MW}^{b_{i}}$

where $i$ is the steam boiler, steam turbine and generator, boiler feed pump, condensate extraction pump and condenser, respectively.

Boiler is subcritical, radiant reheat, dry bottom, natural circulation, single drum, semi-outdoor type, direct fired, balance draft, top supported type having provision for firing coal as the primary fuel. Turbine subsystem is tandem compounded, horizontal, reheat type, single shaft machine under this study. The condenser is used to condense the exhaust steam from the low-pressure turbine and to produce the deepest possible vacuum to maximize the heat drop and the turbine output. The condensate extraction pump is attached to the condenser. The condensate extraction pump $\left(C_{e}\right)$ is a centrifugal, vertical pump, consisting of the pump body, the can, the distributor housing and the driver lantern. It has three units working in parallel with $100 \%$ capacity. Boiler feed pump has one unit working in parallel with $50 \%$ capacity. The curve fit of component cost was obtained from data collected from the literature; the values of empirical constants $a_{i}$ and $b_{i}$ are also listed in Table 1 . The comparisons of curve fits against data for cost of boiler, turbine generator, condenser, civil works, electrical works and piping works are shown in Figs. 1, 2, 3, 4, 5, 6.

The total direct plant cost involves the cost of equipment and other costs and can be written as
$C_{\text {direct }}=C_{\text {Eqp }}+C_{\text {other }}$.

The cost of the equipment, $C_{\mathrm{Eqp}}$, can be written in terms of redundancies of the respective components $\left(N_{i}\right)$ as

$$
\begin{aligned}
C_{\text {Eqp }}= & \sum_{i}^{n}\left(N_{i} C_{i}\right)+C_{\text {piping }}+C_{\text {civil }}+C_{\text {electrical }} \\
& +C_{\text {coalhandling }}+C_{\text {ashhandling }} .
\end{aligned}
$$

Here, ' $N{ }_{i}$ ' represents the number of redundant units of condensate extraction pump and boiler feed pump. In the present study, redundant units are 3 and 1 for condensate extraction pump and boiler feed pump, respectively. The other costs associated with piping, civil works and electrical works can be obtained in the form of Eq. (1) followed by Table 1 . However, the costs of piping works (in INR) can be obtained using the polynomial form as

$$
\begin{aligned}
C_{\text {piping }}= & -895.91 \times(\mathrm{MW})^{2}+3,674,897.1 \times \mathrm{MW} \\
& -145,238,239.3 .
\end{aligned}
$$

In the absence of suitable cost data for the coal handling and ash handling system, the data of the $300 \mathrm{MW}$ plant for the coal handling and ash handling system (Pauschert 2009) are adopted:

$C_{\text {coalhandling }}=f_{\text {conversion }} \times 96 \times 10^{5}$,
$C_{\text {ashhandling }}=f_{\text {conversion }} \times 17 \times 10^{6}$.

The cost due to direct installation, auxiliary services, instrumentation and controls and site preparation can be grouped in another category as

$C_{\text {other }}=\varsigma C_{\text {Eqp }}$.

Here, $\varsigma$ is a factor that accounts for direct installation, auxiliary, instrumentation and control. $\varsigma$ is fixed at 0.65 .

The total indirect plant cost has been associated with engineering and plant start-up, which can be obtained in terms of total equipment cost following Caputo et al. (2005) as

$C_{\text {indirect }}=\xi C_{\text {Eqp }}$.

Here, $\xi$ is a factor that accounts for engineering and plant start-up, which is fixed at 0.22 in the present calculations.

Thus, total capital investment can be defined as the sum of total direct and total indirect plant cost as

$C_{\text {tci }}=C_{\text {direct }}+C_{\text {indirect }}$.

The operating cost (includes the purchasing cost of coal feedstock, maintenance and labour, insurance and cost of power associated with boiler feedwater pumps and condensate extraction pumps for running the thermal power plant) is considered to be paid annually over the lifespan of the coalfired power plant. It is likely to be changed in an economic 
Table 1 Constants in Eq. (1) in the evaluation of component cost (in INR)

\begin{tabular}{lllll}
\hline S. no. & Equipment & $\mathrm{a}$ & $\mathrm{b}$ & References \\
\hline 1 & Steam boiler & $76,132,335.1$ & 0.8 & Caputo et al. (2005); Hasler et al. (2009) \\
2 & Steam turbine and generator & $3,501,170.7$ & 1.2 & Caputo et al. (2005); Pauschert (2009) \\
3 & Feed pumps & 35,000 & 0.6 & Caputo et al. (2005) \\
4 & Cond. extraction pump & 9000 & 0.4 & Caputo et al. (2005) \\
5 & Condenser & $17,306,123.8$ & 0.5 & Caputo et al. (2005); NETL (2012) \\
6 & Civil works & $57,418,809.8$ & 0.5 & Caputo et al. (2005); Pauschert (2009) \\
7 & Electrical works & $59,663,488.1$ & 0.6 & Caputo et al. (2005); Pauschert (2009) \\
\hline
\end{tabular}

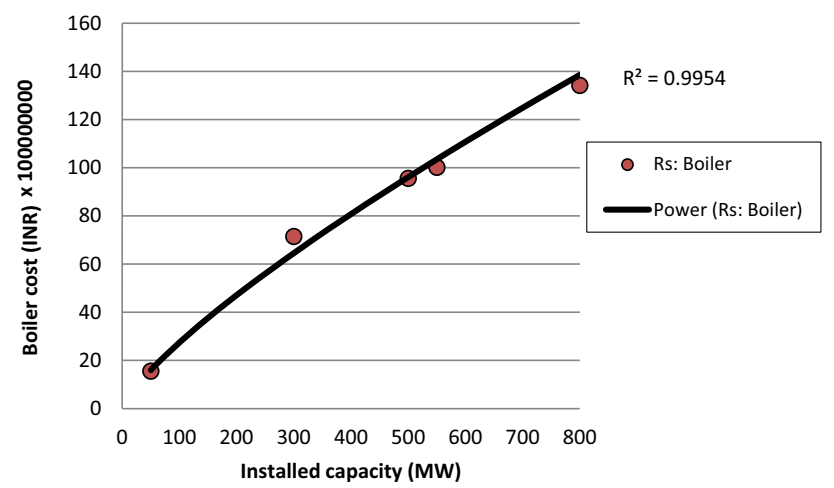

Fig. 1 Comparing curve fit against cost data of boiler in terms of installed capacity

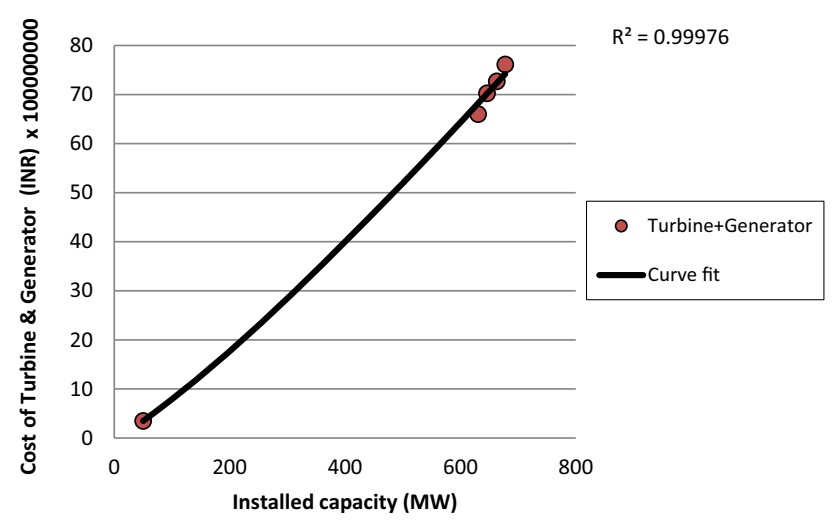

Fig. 2 Comparing curve fit against cost data of turbine generator in terms of installed capacity

climate (i.e. due to current interest rate and escalation rate in the prices of coal, maintenance, labour, insurance and pumping power). Therefore, to account for the influence of interest rate and the escalation rate for the total operating cost over plant life, the present worth factor (PWF) can be defined as

$\mathrm{PWF}_{k}=\frac{1}{(1+i)^{k}}$.

Thus, the lifetime cost of coal or fuel, maintenance, labour, insurance and pumping power can be obtained in

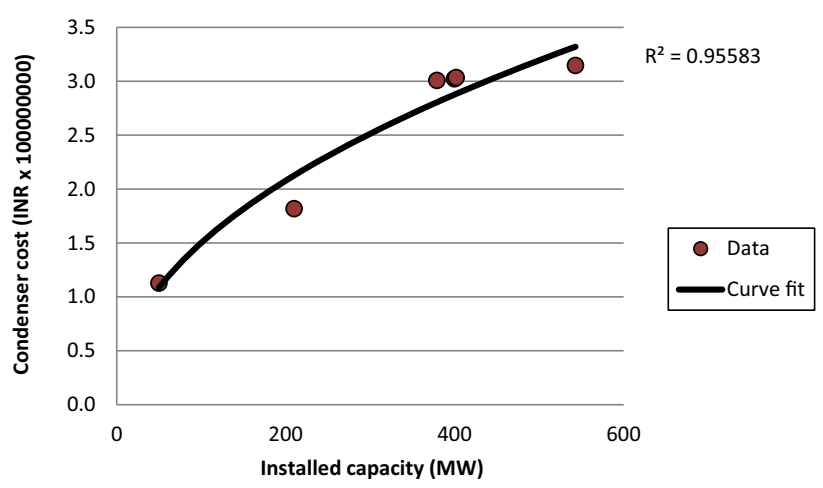

Fig. 3 Comparing curve fit against cost data of condenser in terms of installed capacity

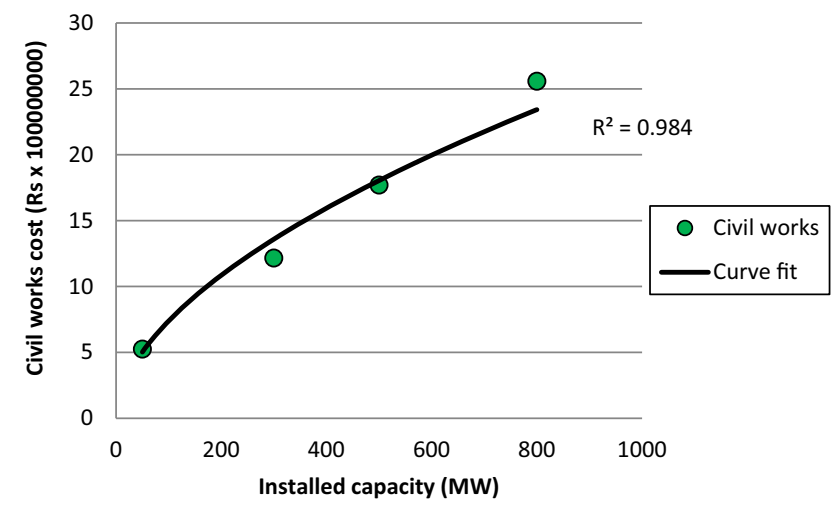

Fig. 4 Comparing curve fit against cost data of civil works in terms of installed capacity

terms of PWF and the escalation rate following $\mathrm{Li}$ and Priddy (1985) as

Coal or fuel cost

$C_{\text {coal }}=\sum_{k=1}^{\mathrm{pl}}\left(\mathrm{PWF}_{k} \times m_{\text {coal }, k} \times C_{c c}(1+K)^{(k-1)}\right)$.

The maintenance cost is

$C_{\text {maint }}=\sum_{k=1}^{\mathrm{pl}}\left(\mathrm{PWF}_{k} \times 0.015 \times C_{\mathrm{tci}}(1+Q)^{(k-1)}\right)$. 


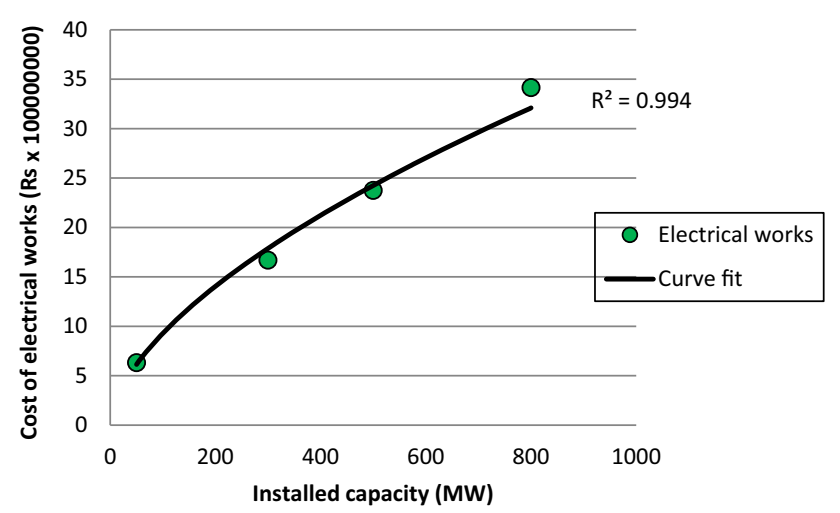

Fig. 5 Comparing curve fit against cost data of electrical works in terms of installed capacity

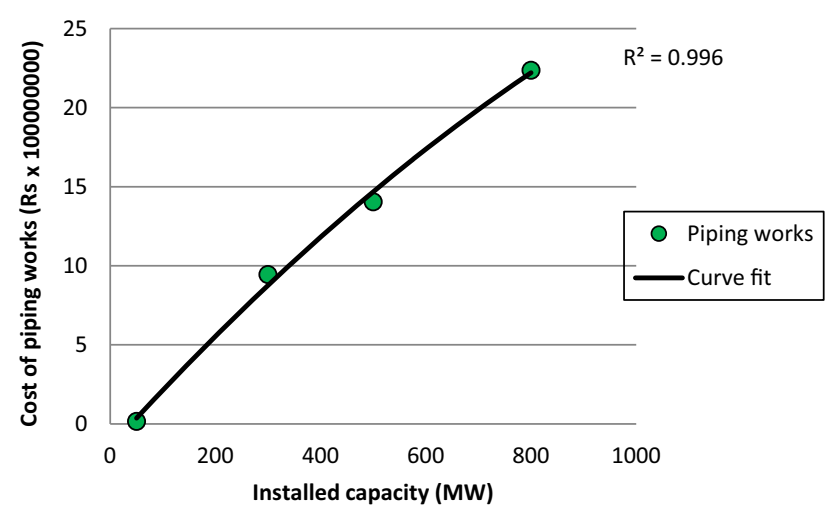

Fig. 6 Comparing curve fit against cost data of piping works in terms of installed capacity

The labour cost is

$C_{\text {lab }}=\sum_{k=1}^{\mathrm{pl}}\left(\mathrm{PWF}_{k} \times n_{L} \times C_{s}(1+J)^{(k-1)}\right)$.

The insurance cost is

$C_{\mathrm{ins}}=\sum_{k=1}^{\mathrm{pl}}\left(\mathrm{PWF}_{k} \times 0.01 \times C_{\mathrm{tci}}(1+O)^{(k-1)}\right)$.

The pumping cost is

$$
\begin{aligned}
C_{\text {pumping }}= & \sum_{k=1}^{\mathrm{pl}}\left(\mathrm{PWF}_{k} \times 8760 A v_{\text {overall }}\right. \\
& \left.\times\left[\sum_{j=1}^{N} \frac{\left(\frac{m_{j}}{\rho_{\text {water }}}\right) \times \Delta P_{j}}{\eta_{\text {pump } j}}\right] \times c_{\mathrm{ep}}(1+S)^{(k-1)}\right) .
\end{aligned}
$$

In Eq. (14), the escalation rate on insurance $(\mathrm{O})$ is assumed to be zero.

Here, $\mathrm{Av}_{\text {overall }}, N, m, \eta_{\text {pump }}$ and $\Delta P$ are the overall availability, number of pumps, pump efficiency, mass flow rate and pressure drop through the $j$ th pump, respectively.
Also, ' $n_{L}$ ' is the number of personnel employed, ' $C$ ' is the cost in INR, while subscripts maint, ins, ep, cc and lab correspond to maintenance, insurance, price of electricity (INR/MWhr), coal cost and average annual labour cost (individual), respectively. In the present case, $\eta_{\text {pump }}$ has been taken to be $90 \%$. The maintenance and insurance costs are taken to be 1.5 and $1 \%$ of the total capital investment obtained from the literature. The coal storage, fuel handling system and fume treatment costs are neglected in the present work. The taxes and financial charges have been neglected in this work.

The lifetime cost of purchasing cost of coal feedstock, maintenance and labour, insurance and cost of power associated with boiler feedwater pumps and condensate extraction pumps for running the thermal power plant can be calculated as

$$
C_{o}=C_{\text {coal }}+C_{\text {maint }}+C_{\text {lab }}+C_{\mathrm{ins}}+C_{\text {pumping }} \text {. }
$$

Likewise, the revenue over life span can be obtained from the sale of electricity in terms of PWF as

$$
R_{\mathrm{an}}=f_{\mathrm{MW}} \sum_{k=1}^{\mathrm{pl}}\left(\mathrm{PWF}_{k} \times \mathrm{MW} \times 8760 \mathrm{Av}_{\text {overall }} \times c_{\mathrm{ep}}(1+S)^{(k-1)}\right) .
$$

Caputo et al. (2005) reported that $10 \%$ of the total revenue is consumed in internal affairs of the plant, which includes the pumping cost itself. Since we have included the pumping cost in the operating cost itself, the necessary adjustment in the net electric output would be required. From a baseline run, it was observed that the pumping cost was hardly $1 \%$ of the total revenue. Therefore, the value of $f_{\text {Mw }}$ was fixed at $91 \%$.

For assessment of the economic effectiveness of the investments, the NPV method is most frequently used. In the present work, therefore, the NPV method was employed. The expression of the net present value of plant on lifetime basis can be written as

$\mathrm{NPV}_{\text {lifetime }}=R_{\text {lifetime }}-\left(C_{o}+C_{\text {tci }}\right)_{\text {lifetime }}$.

The total number of people deputed in the plant along with their salary is represented in Table 2. The average personnel salary on an annual basis is deduced from the plant (see Table 2).

The current interest rate is fixed at $9 \%$. The average electricity price at present is taken to be $4500 \mathrm{INR} / \mathrm{MWhr}$.

Table 2 Data of 210 MW plant for average salary of plant personnel as deduced from plant records

\begin{tabular}{lll}
\hline $\begin{array}{l}\text { Total personnel } \\
\text { deployed } \\
\text { in 210 MW unit }\end{array}$ & $\begin{array}{l}\text { Total monthly } \\
\text { salary of plant } \\
\text { personnel (INR) }\end{array}$ & $\begin{array}{l}\text { Average monthly } \\
\text { salary (INR) }\end{array}$ \\
\hline 233 & $6,025,000$ & $25,858.4$ \\
\hline
\end{tabular}


Table 3 Input data collected from literature and plant records

\begin{tabular}{llll}
\hline Parameter & Notation & Value & References \\
\hline Number of labourers employed & $n_{L}$ & 233 & $*$ \\
Average labour cost on annual basis & $C_{\mathrm{s}}$ & $310,300.3(\mathrm{INR} /$ year $)$ & $*$ \\
Fuel cost & $C \mathrm{cc}$ & $2.7(\mathrm{INR} / \mathrm{kg})$ & $*$ \\
Current price of electricity & $C_{\mathrm{ep}}$ & $4500(\mathrm{INR} / \mathrm{MWhr})$ & HERC (2013) \\
Factor to account for power consumption & $f_{\mathrm{MW}}$ & 0.9 & Caputo et al. (2005) \\
$\quad$ within the plant & $‘ \cdot$ & $9 \%$ & $*$ \\
Interest rate & & & \\
\hline
\end{tabular}

* Data deduced from plant records
Plant life is assumed to be 35 years. Other input information, including fuel cost, factor to account for expenses due to installation, instrumentation, engineering and plant startup, factor to account for power consumption within plant, interest rate and escalation rate have been represented in Table 3.

Using the above input information, the effect of various variables is investigated on plant operating cost (i.e. fuel cost, pumping cost, insurance and maintenance cost), total capital investment, revenue and net present value.

\section{Results and discussion}

\section{Plant life}

The effect of variation in total plant life has been highlighted on lifetime cost associated with plant operation (i.e. coal feedstock, maintenance and labour, insurance and cost of pumping power due to feedwater pumps and boiler extraction pumps), total capital investment, revenue and net present value of plant, as shown in Figs. 7, 8. In Fig. 7, the effect on lifetime cost components such as fuel, maintenance, insurance, labour and pumping has been plotted against plant life, which varies from 0 to 35 years with an interval of

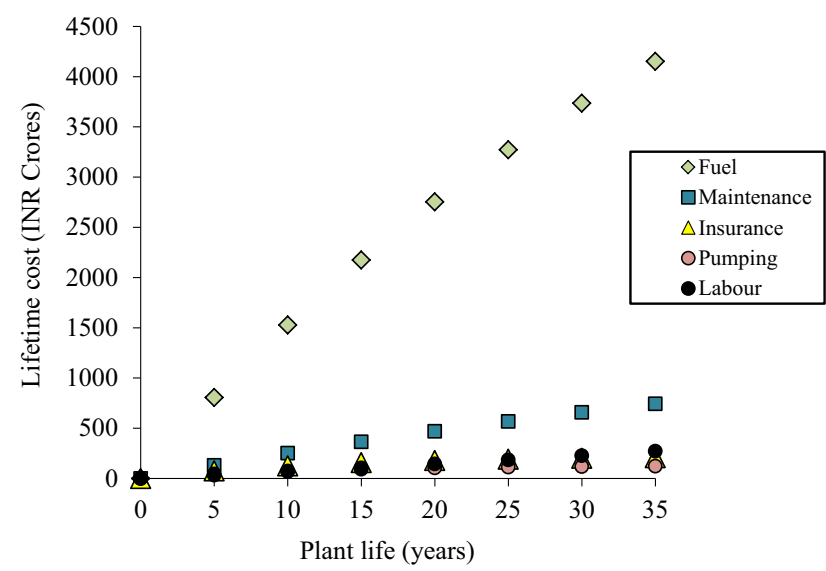

Fig. 7 Effect of plant lifetime on fuel cost, maintenance cost, insurance cost, pumping cost and labour cost; plant load $=210 \mathrm{MW}$

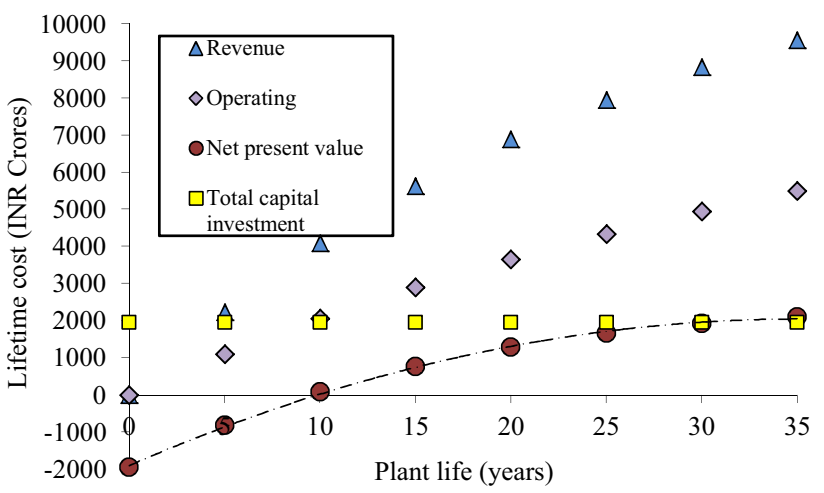

Fig. 8 Effect of plant life on total capital investment, total operating cost, total revenue and net present value; plant load $=210 \mathrm{MW}$

5 years. The total fuel cost, maintenance, insurance, labour cost and pumping cost over the plant life increases with plant life, as expected. The fuel cost is observed to be highly sensitive, while pumping cost is observed to be least sensitive for the above range of plant life.

Figure 8 highlights the effect on total operating cost, total capital investment, revenue earned and net present value with plant life up to 35 years. Total operating cost, revenue and net present value of the plant also improve with plant life. Lifetime plant operating cost increases up to 5397.6 INR crores, while total revenue increases up to 9421.7 INR crores by increasing plant life from 5 to 35 years and plant net present value improves from -1965.4 INR crores to 2058.8 INR crores for encountering variation in plant life. At the present time frame, the total capital investment remains constant. It is observed from predictions that payback (or gestation period) of the plant is nearly 10 years. Beyond this period, the plant starts showing a profit.

\section{Plant load}

The effect of variation in plant load from 168 to $221 \mathrm{MW}$ on a $210 \mathrm{MW}$ capacity coal-fired power plant was investigated on total fuel cost, pumping cost, insurance and maintenance cost, labour cost, total capital investment, 
revenue and net present value of plant on lifetime basis has been highlighted in Figs. 9 and 10. Figure 9 shows that, except labour cost, all costs improve with plant load. Fuel cost, maintenance cost, insurance cost and pumping cost increases from 3262.4 to $4261.9,641.11$ to $775.19,178.08$ to 215.32 and 91.23 to 126.89 INR crores, respectively. The fuel cost is observed to be highly sensitive, while pumping cost has been found to be least sensitive.

Figure 10 represents the effect of plant load on total operating cost, equipment, revenue and net present value of the plant. As plant life increases, the total operating cost, total capital investment, revenue and plant net present value were observed to be improved, as expected. The typical increase in total operating cost, revenue, total capital investment and net present value of the plant increased from 4445.1 to $5651.6,7537.3$ to $9915.2,1685.3$ to 2037.7 and 1406.9 to 2225.9 INR crores, respectively by increasing the plant load from 168 to $221 \mathrm{MW}$.

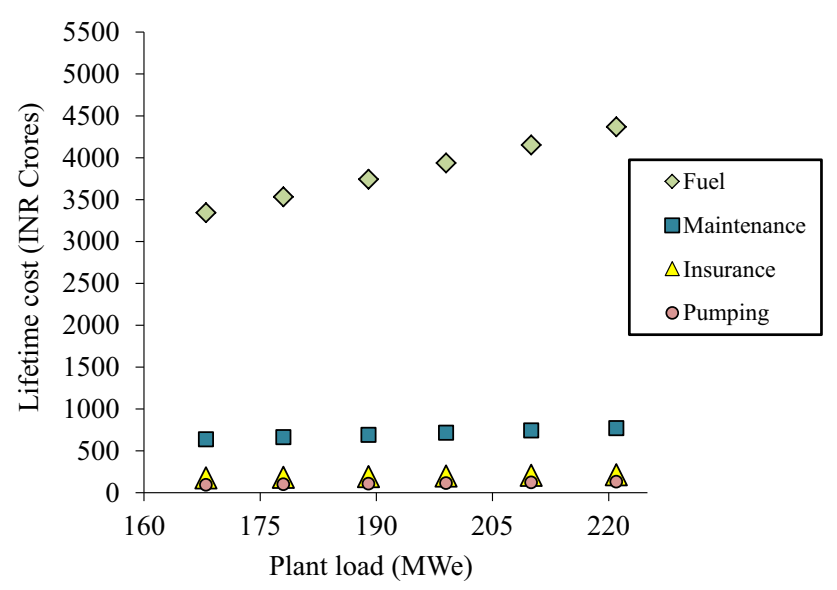

Fig. 9 Effect of plant load on lifetime total fuel cost, total maintenance cost and total labour cost; plant load $=210 \mathrm{MW}$

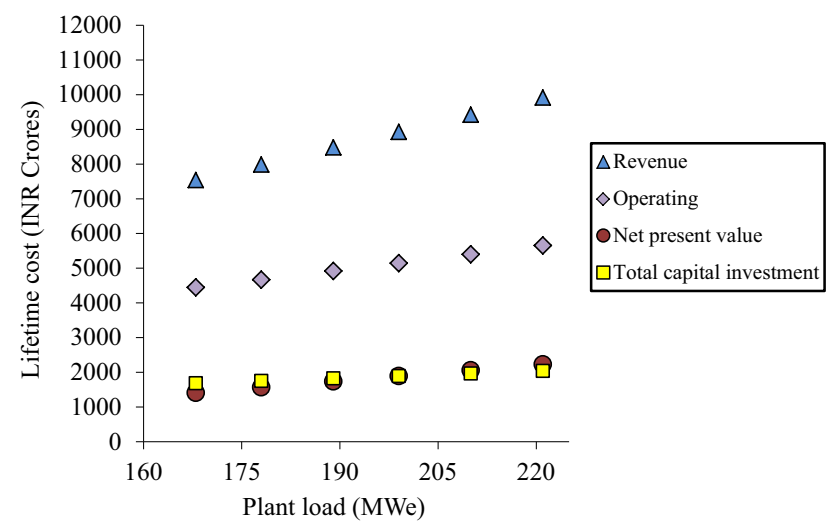

Fig. 10 Effect of plant load on total capital investment, total operating cost, total revenue and net present value; load $=210 \mathrm{MW}$

\section{Interest rate}

The effect of variation in the interest rate has been highlighted on accumulated lifetime total fuel cost, pumping cost, insurance and maintenance cost, labour cost, total capital investment, revenue and net present value as represented in Figs. 11 and 12. In Fig. 11, the effects on fuel, maintenance, insurance, labour and pumping costs have been plotted against the interest rate range from 9 to $15 \%$ on an annual basis. As expected, the total fuel cost, insurance, pumping, labour and maintenance charges decreases as the interest rate increases.

Figure 12 highlights the effect on total operating cost, total capital investment, revenue earned and net present value on a lifetime basis against the interest rate. The total operating cost, revenue and net present value of the plant decrease as the interest rate increases. Plant net present

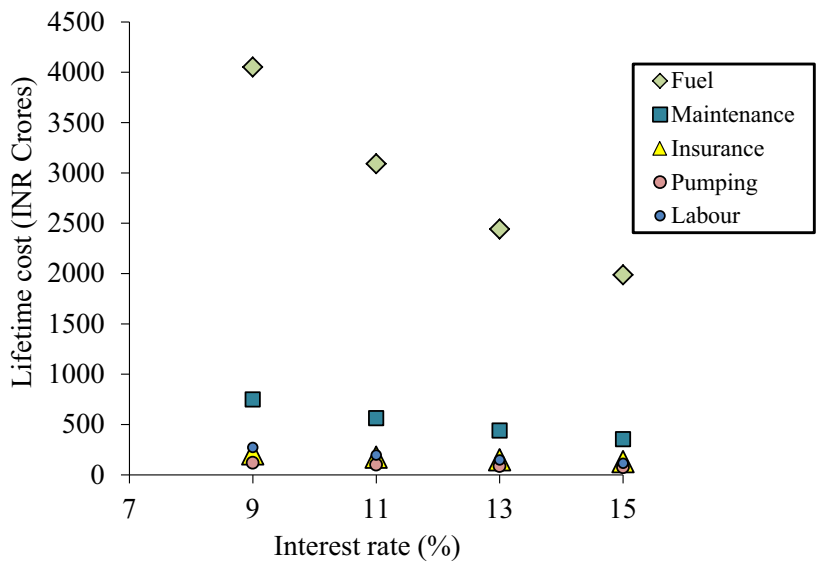

Fig. 11 Effect of interest rate on plant lifetime total fuel cost, total maintenance cost, total insurance, total pumping and total labour cost; plant load $=210 \mathrm{MW}$

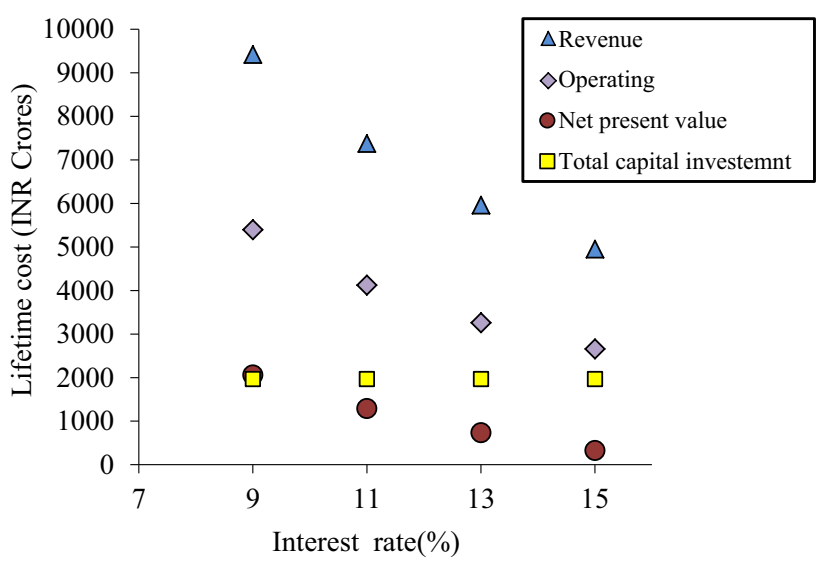

Fig. 12 Effect of interest rate on plant lifetime total capital investment, total operating cost, total revenue and net present value; plant load $=210 \mathrm{MW}$ 
value decreases from 2058.8 to 326.36 INR crores with increasing interest rates from 9 to $15 \%$ on an annual basis.

\section{Escalation rate}

In power plants, economic factors vary from year to year. To handle the fluctuations in the economic climate, it is usual practice to include a constant escalation rate for each module as listed in Table 4. Using information regarding escalation rates and without using escalation rate, the various costs on lifetime basis (total fuel cost, pumping cost, insurance and maintenance cost, labour cost, total capital investment, revenue and net present value of the plant) have been plotted on bar chart as shown in Figs. 13, 14. The effect of escalation rates on labour cost was not considered in the present work. In Fig. 13, the effect on accumulated operating cost components such as fuel, maintenance, insurance cost, labour and pumping cost, with and without escalation rate, has been plotted at 210 MW plant load. With escalation, costs of fuel, maintenance, insurance, labour and pumping have been observed to be higher than the case without escalation. The fuel cost is found to be highly sensitive as it is the major share of operating cost.

Figure 14 highlights the effect of escalation rate on the total operating cost, revenue earned, total capital

Table 4 Escalation rates on various costs

\begin{tabular}{llll}
\hline Parameter & Notation & $\begin{array}{l}\text { Escalation rate } \\
(\%)\end{array}$ & Reference \\
\hline $\begin{array}{l}\text { Current price of } \\
\text { electricity }\end{array}$ & $\mathrm{S}$ & 5 & $\begin{array}{c}\text { Ranganathan } \\
(2005)\end{array}$ \\
$\begin{array}{l}\text { Labour salary } \\
\text { Fuel cost }\end{array}$ & $\mathrm{J}$ & 10 & $\boldsymbol{\star}$ \\
Maintenance cost & $\mathrm{K}$ & 6.6 & Saxena (2013) \\
\hline
\end{tabular}

* Data deduced from plant records for salary

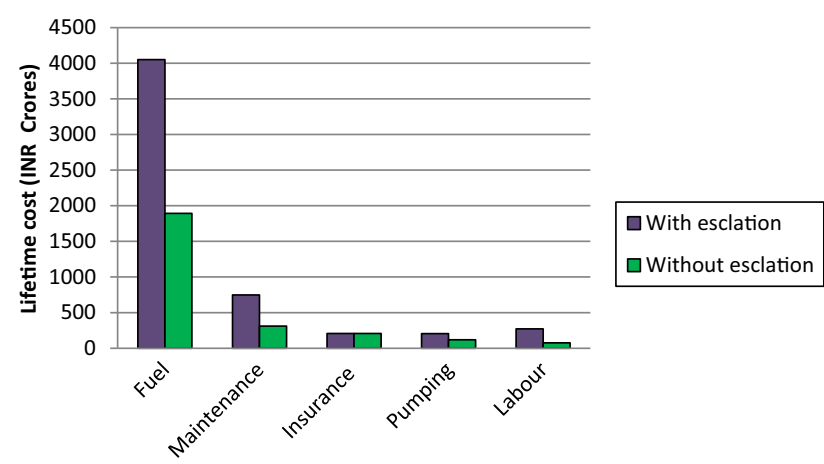

Fig. 13 Comparing the effect of escalation on plant lifetime total fuel cost, total maintenance cost, total insurance cost, total pumping cost and total labour cost; plant load $=210 \mathrm{MW}$

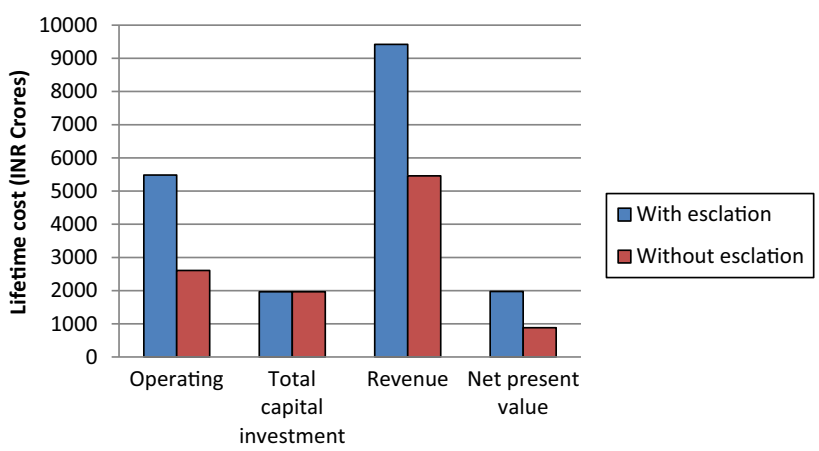

Fig. 14 Comparing the effect of escalation on plant lifetime total operating cost, total capital investment, total revenue and net present value of plant; load $=210 \mathrm{MW}$

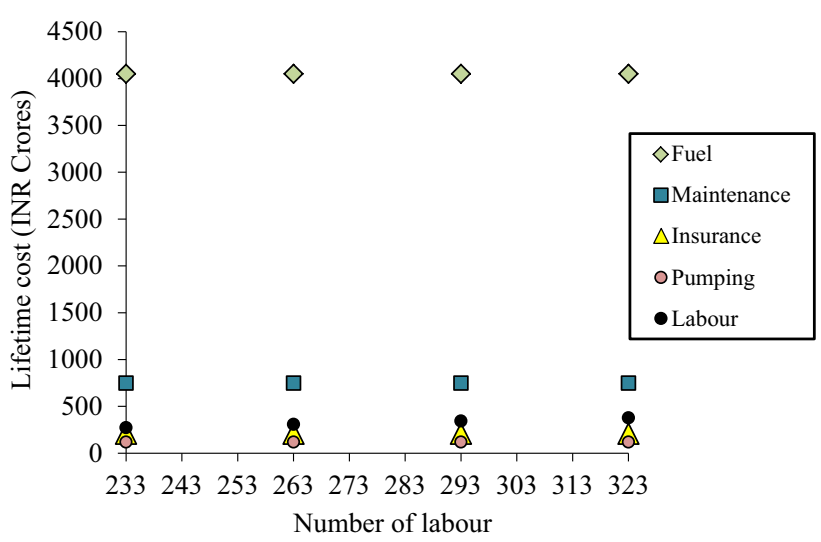

Fig. 15 Effect of number of labourers employed on plant lifetime total fuel cost, total maintenance cost, total insurance cost, total pumping cost and total labour cost; plant load $=210 \mathrm{MW}$

investment and net present value of the plant. This figure also represents that the total capital investment is unchanged, as expected. The total operating cost, revenue earned and net present value of plant with escalation rates were observed to be higher as compared to the case without any escalation.

The various accumulated costs (total fuel cost, pumping cost, insurance and maintenance cost, labour cost, total capital investment, revenue and net present value of the plant) with and without escalation rates with plant life of 35 years have been shown in Figs. 13 and 14. The effect of escalation rates on pumping and labour cost has not been considered in the present work. In Fig. 13, the effect on accumulated operating cost components such as fuel, maintenance, insurance cost, labour and pumping cost, with and without escalation rates has been plotted at $210 \mathrm{MW}$ plant load. Fuel cost, maintenance, insurance, labour and pumping cost with escalation rates has been observed to be 4050.8, 747.68, 207.68, 272.3 and 119.06 INR crores, respectively. On the other hand, these costs without escalation rates were observed to be 1892.8 , 
311.52, 207.68, 272.3 and 119.06 INR crores, respectively. Figure 14 highlights the effect on total operating cost, revenue earned, total capital investment and net present value of the plant. Total operating cost, revenue earned and net present value of the plant with escalation rates was observed to be 5397.6, 9421.7 and 2058.8, respectively. If no escalation rates are introduced, the total operating cost,

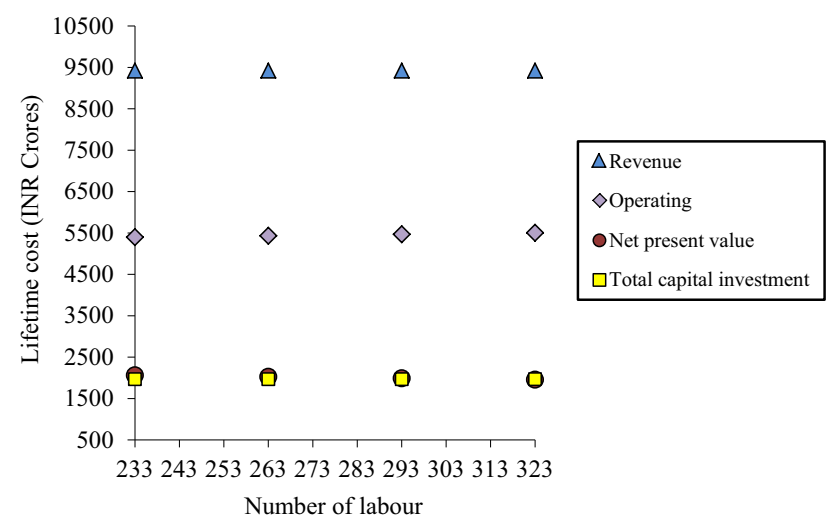

Fig. 16 Effect of number of labourers employed on plant lifetime total capital investment, total operating cost, total revenue and net present value; load $=210 \mathrm{MW}$ revenue earned and net present value of the plant are 2607.4, 5456.7 and 883.95 INR crores, respectively.

\section{Labour}

The effect of variation in the number of labourers employed has been highlighted on the accumulated total fuel cost, pumping cost, insurance and maintenance cost, labour cost, fixed cost, operating cost, revenue and net present value of the plant as shown in Figs. 15 and 16. Since the contribution of labour cost to operating cost is very small, the variation in all trends of operating cost, revenue and net present value is marginal.

\section{Conclusions}

The effect of various parameters on plant economics has been observed in this study and the following conclusions have been achieved. In case of plant life ranging from 5 to 35 years, the fuel cost is observed to be highly sensitive, while pumping cost is observed to be least sensitive. It is also concluded that payback (or gestation period) of the plant is nearly 10 years. Increase in interest rate decreases the value of various plant costs. The total operating cost,

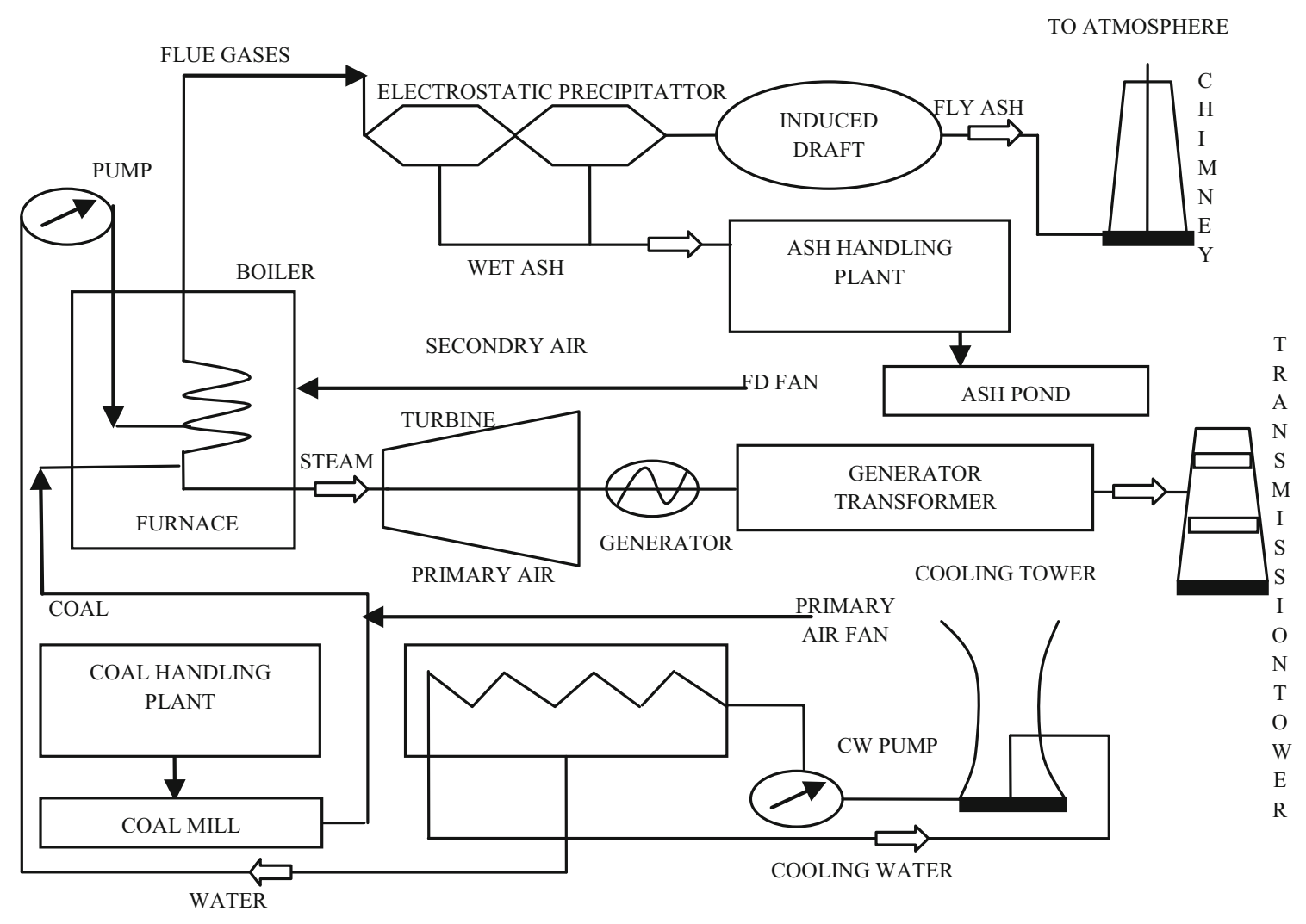

Fig. 17 Schematic diagram of the physical system 
revenue earned, net present value of plant, costs of fuel, maintenance, insurance, labour and pumping with escalation rates have been observed to be higher than the case without escalation. Since labour cost influences the operating cost at a slow rate, the variation in all trends of operating cost, revenue and net present value is marginal. In case of plant (see Fig. 17), results predict that plant life, interest rate and the escalation rate observed to be very sensitive on plant economics in comparison to other factors under study.

Open Access This article is distributed under the terms of the Creative Commons Attribution 4.0 International License (http://creativecommons.org/licenses/by/4.0/), which permits unrestricted use, distribution, and reproduction in any medium, provided you give appropriate credit to the original author(s) and the source, provide a link to the Creative Commons license, and indicate if changes were made.

\section{References}

Caputo AC, Palumbo M, Pelagagge PM, Scacchia F (2005) Economics of biomass energy utilization in combustion and gasification plants: effect of logic variables. Biomass Bioenergy 28:35-51

Davison J (2007) Performance and costs of power plants with capture and storage of $\mathrm{CO}_{2}$. Energy 32:1163-1176

Giri BC, Dohi T (2004) Optimal lot sizing for an unreliable production system based on net present value approach. Int $\mathrm{J}$ Prod Econ 92:157-167
Haryana Electricity Regulatory Commission (HERC) (2013) Commission's order on generation tariff for Haryana Power Generation Corporation Limited, Panchkula, India, pp 1-64

Hasler D, Rosenquist W, and Gaikwad R (2009) New coal-fired power plant performance and cost estimates. Sargent and Lundy project, pp 1-82

Li KM, Priddy AP (1985) Power plant system design. Wiley, New York

Madlener R, Stoverink S (2012) Power plant investments in the Turkish electricity sector: a real options approach taking into account market liberalization. Appl Energy 97:124-134

Manninen J, Zhu XX (1998) Thermodynamic analysis and mathematical optimization of power plants. Comput Chem Eng 22:S537-S544

National Energy Technology Laboratory (2012) Final report on updated costs (June 2011 Basis) for selected bituminous baseline cases. http://www.netl.doe.gov

Pauschert D (2009) Study of equipment prices in the power sector. ESMAP Technical Paper, pp 1-95

Peters M, Timmerhaus K, West R (1991) Plant design and economics for chemical engineers. McGraw-Hill Inc., New York

Ranganathan M (2005) Can co-ops become energy producers too. Master of Science Thesis, Energy and Resources Group of the University of California, Berkeley

Remer DS, Nieto AP (1995) A compendium and comparison of 25 project evaluation techniques. Part 1: net present value and rate of return methods. Int J Prod Econ 42(1):79-96

Saxena AK (2013) Central electricity regulatory commission. Notification, India, pp 1-9

Zhang Q, Zhou D, Zhou P, Ding H (2013) Cost analysis of strawbased power generation in Jiangsu Province. China 102:79-96 